\title{
Translating Mutagenesis into Carcinogenesis
}

\section{Stephen G. Grant*}

Pharmaceutical Sciences, College of Pharmacy, Nova Southeastern University, Fort Lauderdale, Florida 33328-2018, USA

\section{Editorial}

The Journal of Carcinogenesis and Mutagenesis follows a now century-old tradition of publishing investigations into the genetic, i.e., mutational, basis of cancer. Insights from our field have been, and continue to be, critically important for human cancer treatment, detection and prevention.

Genotoxicity provided the rationale for systemic cancer therapy, which is only, now, after 70 years or so, giving way to new modalities. It is becoming standard practice to evaluate the genome and/or transcriptome of cancers in order to tailor targeted therapies using antibodies (and now, fusion antibodies), small molecule inhibitors, and, in the near future, microRNAs, both native and engineered. These methods usually target the altered or over expressed products of activated oncogenes; normal cellular genes activated by site-specific mutation.

Altered cellular proteins activated oncogenes or inactivated (i.e., DNA hypermethylated) tumor suppressor genes can also be found in cellular surveys or bodily fluids, allowing for detection of the cancer prior to overt tumorigenesis, or even at the preneoplastic stage.

It is, however, at the level of prevention where the field of genotoxicity has made its greatest contributions to human health, and where it may play its most important roles in the future. It is impossible to estimate the number of cancer cases prevented by the governmental and industrial screening of chemicals and products for mutagenic activity, which have then not been introduced into wide human contact.

Arguably, however, we have not been as successful at identifying and removing carcinogenic agents already in the environment. The classification of such agents at the highest, actionable, level requires unambiguous human epidemiological data, a level of stringency that is almost impossible to attain. Indeed, it is almost as if a Hiroshima-scale exposure event is required for every individual carcinogenic agent. Real-world exposures are unlikely to provide the power necessary for strong associations with a disease such as cancer, which has long been known to require multiple events.

Rather than focusing on the carcinogen, however, the multistep model of cancer provides an alternate approach for human carcinogenesis, analysis of humans themselves. The rationale is simple: if multiple events are required to induce cancer, and most, if not all such events are mutations (we must leave room for epigenetic events, mechanisms that mimic genetic events [1]), then cancer should occur differentially in individuals and populations with high frequencies of mutation.

This was the basis of a series of studies applying our oldest mutational assays, cytogenetic analyses of lymphocyte chromosomal aberrations, micronuclei and sister chromatid exchange prospectively to populations in a number of countries around the world [2-6]. It quickly became clear that chromosomal aberration frequency was predictive of subsequent cancer incidence and/or mortality, an observation that has held up over time [7]. Indeed, with the accumulation of studies and follow-up time, micronucleus frequency was also found to be predictive of cancer [8,9]. Just to show that all cytogenetic analyses are not equally applicable, sister chromatid exchange remains unpredictive.

An important aspect of these studies has been that although the original populations chosen were often targeted due to known or expected exposures, the authors acknowledge the importance of and variability of individual susceptibility in their models [10]. Too often, such studies have been weighted towards either exposure (toxicologists) or predisposition (geneticists) with little allowance for the interaction of such factors. The integration of individual response into exposure measurements was advocated in 1983 by Hsu [11], and we have observed considerable inter-individual variability in measurement of human DNA repair capacity [12].

So, with two successful, predictive measures of cancer risk validated and available, why has there been no effort to apply these techniques in population screening? One reason appears to be the lack of specificity of the results. Since these studies amalgamate populations assayed in different laboratories, the authors felt justified in separating the assay results only in tertiles, with the highest tertile showing a consistent, but relatively modest relative risk of cancer on the order of two-fold. There also seems to be some perceived resistance to the minimally invasive phlebotomy required to obtain samples for these analyses, with current efforts apparently attempting to standardize assay procedures and shift the focus to non-invasively obtainable buccal cells [13]. In a world where single measurements are predictive of cancer and blood samples are available after any doctor visit, this seems like progress sideways rather than forward.

Another approach to measurement of human somatic mutation has been the development of a number of gene-specific assays [14]. Due to the feasibility requirement of detecting mutations with singlehit kinetics in a diploid organism (humans), there have never been many such assays, with early techniques targeting the $\beta$-hemoglobin and HLA genes having fallen by the wayside, only to be replaced by methods focusing on the T cell receptor [15] and PIG-A [16,17] loci.

The two most widely applied of these types of methods, the HPRT assay in lymphocytes and the GPA assay in erythrocytes, have also been applied in retrospective studies comparing the mutation frequencies in newly diagnosed cancer patients and controls [18]. In both assays, the patient population exhibited a 1.5 -fold increased mutation frequency that was statistically significant.

*Corresponding author: Stephen G. Grant, Pharmaceutical Sciences, College of Pharmacy, Nova Southeastern University, Fort Lauderdale, Florida 33328-2018, USA, E-mail: grast01@nova.edu

Received June 19, 2012; Accepted June 19, 2012; Published June 21, 2012

Citation: Grant SG (2012) Translating Mutagenesis into Carcinogenesis. J Carcinogene Mutagene 3:e106. doi:10.4172/2157-2518.1000e106

Copyright: ( 2012 Grant SG. This is an open-access article distributed under the terms of the Creative Commons Attribution License, which permits unrestricted use, distribution, and reproduction in any medium, provided the original author and source are credited. 
The GPA assay was developed as a biodosimeter for ionizing radiation, but has since been validated in a number of exposure scenarios [19]. It has also been found to be diagnostic for certain inherited DNA repair deficiency syndromes $[20,21]$. If "outliers" are discriminated in the normal and cancer patient populations as defined for diagnostic purposes, they have an odds ratio of over 4 of preferentially occurring among the patients. Although the proportion of such individuals with unusually high GPA mutation frequencies varies significantly with age [22], it averages about $10 \%$ of the normal population, a more manageable proportion for targeted analysis, monitoring or treatment.

Several other types of analysis have also been reported to be predictive of cancer in human populations, such as mutagen sensitivity [23] and screening of blood for oncogene mutations [24] and methylated tumor suppressor genes [25]. Perhaps it is time to shift our emphasis from debating the best tests for chemical screening (again) $[26,27]$ to determining the best set of tests to prospectively defining cancer risk in human populations?

\section{References}

1. Grant SG, Campbell CE, Duff C, Toth SL, Worton RG (1989) Gene inactivation as a mechanism for the expression of recessive phenotypes. Am J Hum Genet 45: 619-634.

2. Hagmar L, Brøgger A, Hansteen IL, Heim S, Högstedt B, et al. (1994) Cancer risk in humans predicted by increased levels of chromosomal aberrations in lymphocytes: Nordic study group on the health risk of chromosome damage. Cancer Res 54: 2919-2922.

3. Bonassi S, Abbondandolo A, Camurri L, Dal Prá L, De Ferrari M, et al. (1995) Are chromosome aberrations in circulating lymphocytes predictive of future cancer onset in humans? Preliminary results of an Italian cohort study. Cancer Genet Cytogenet 79: 133-135.

4. Liou SH, Lung JC, Chen YH, Yang T, Hsieh LL, et al. (1999) Increased chromosome-type chromosome aberration frequencies as biomarkers of cancer risk in a blackfoot endemic area. Cancer Res 59: 1481-1484.

5. Rossner $\mathrm{P}$, Boffetta $\mathrm{P}$, Ceppi M, Bonassi S, Smerhovsky Z, et al. (2005) Chromosomal aberrations in lymphocytes of healthy subjects and risk of cancer. Environ Health Perspect 113: 517-520.

6. Boffetta P, van der Hel O, Norppa H, Fabianova E, Fucic A, et al. (2007) Chromosomal aberrations and cancer risk: results of a cohort study from Central Europe. Am J Epidemiol 165: 36-43.

7. Bonassi S, Norppa H, Ceppi M, Strömberg U, Vermeulen R, et al. (2008) Chromosomal aberration frequency in lymphocytes predicts the risk of cancer: results from a pooled cohort study of 22358 subjects in 11 countries. Carcinogenesis 29: 1178-1183.

8. Bonassi S, Znaor A, Ceppi M, Lando C, Chang WP, et al. (2007) An increased micronucleus frequency in peripheral blood lymphocytes predicts the risk of cancer in humans. Carcinogenesis 28: 625-631.

9. Murgia E, Ballardin M, Bonassi S, Rossi AM, Barale R (2008) Validation of micronuclei frequency in peripheral blood lymphocytes as early cancer risk biomarker in a nested case-control study. Mutat Res 639: 27-34.

10. Bonassi S (1999) Combining environmental exposure and genetic effect measurements in health outcome assessment. Mutat Res 428: 177-185.

11. Hsu TC (1983) Genetic instability in the human population: a working hypothesis. Hereditas 98: 1-9.

12. Latimer JJ, Nazir T, Flowers LC, Forlenza MJ, Beaudry-Rodgers K, et al. (2003) Unique tissue-specific level of DNA nucleotide excision repair in primary human mammary epithelial cultures. Exp Cell Res 291: 111-121.

13. Bonassi S, Coskun E, Ceppi M, Lando C, Bolognesi C, et al. (2011) The HUman MicroNucleus project on eXfoLiated buccal cells (HUMN $(X L))$ : the role of lifestyle, host factors, occupational exposures, health status, and assay protocol. Mutat Res 728: 88-97.

14. Albertini RJ, Nicklas JA, O'Neill JP, Robison SH (1990) In vivo somatic mutations in humans: measurement and analysis. Annu Rev Genet 24: 305326.
15. Kyoizumi S, Akiyama M, Hirai Y, Kusunoki Y, Tanabe K, et al. (1990) Spontaneous loss and alteration of antigen receptor expression in mature CD4+ T cells. J Exp Med 171: 1981-1999.

16. Ware RE, Pickens CV, DeCastro CM, Howard TA (2001) Circulating PIG-A mutant $\mathrm{T}$ lymphocytes in healthy adults and patients with bone marrow failure syndromes. Exp Hematol 29: 1403-1409.

17. Dobrovolsky VN, Elespuru RK, Bigger CA, Robison TW, Heflich RH (2011) Monitoring humans for somatic mutation in the endogenous PIG-a gene using red blood cells. Environ Mol Mutagen 52: 784-794.

18. Grant SG (2001) Molecular epidemiology of human cancer: biomarkers of genotoxic exposure and susceptibility. J Environ Pathol Toxicol Oncol 20: 245261.

19. Grant SG, Bigbee WL (1993) In vivo somatic mutation and segregation at the human glycophorin A (GPA) locus: phenotypic variation encompassing both gene-specific and chromosomal mechanisms. Mutat Res 288: 163-172.

20. Grant SG, Reeger W, Wenger SL (1997) Diagnosis of ataxia telangiectasia with the glycophorin A somatic mutation assay. Genet Test 1: 261-267.

21. Evdokimova VN, McLoughlin RK, Wenger SL, Grant SG (2005) Use of the glycophorin A somatic mutation assay for rapid, unambiguous identification of Fanconi anemia homozygotes regardless of GPA genotype. Am J Med Genet A 135: 59-65.

22. Bigbee WL, Fuscoe JC, Grant SG, Jones IM, Gorvad AE, et al. (1998) Human in vivo somatic mutation measured at two loci: individuals with stably elevated background erythrocyte glycophorin A (gpa) variant frequencies exhibit norma T-lymphocyte hprt mutant frequencies. Mutat Res 397: 119-136.

23. Wu X, Gu J, Spitz MR (2007) Mutagen sensitivity: a genetic predisposition factor for cancer. Cancer Res 67: 3493-3495.

24. Pathak AK, Bhutani M, Kumar S, Mohan A, Guleria R (2006) Circulating cellfree DNA in plasma/serum of lung cancer patients as a potential screening and prognostic tool. Clin Chem 52: 1833-1842.

25. Van De Voorde L, Speeckaert R, Van Gestel D, Bracke M, De Neve W, et al. (2012) DNA methylation-based biomarkers in serum of patients with breast cancer. Mutat Res.

26. Kirkland D, Aardema M, Henderson L, Müller L (2005) Evaluation of the ability of a battery of three in vitro genotoxicity tests to discriminate rodent carcinogens and non-carcinogens I. Sensitivity, specificity and relative predictivity. Muta Res 584: 1-256.

27. Knight AW, Little S, Houck K, Dix D, Judson R, et al. (2009) Evaluation of high-throughput genotoxicity assays used in profiling the US EPA ToxCast chemicals. Regul Toxicol Pharmacol 55: 188-199. 